Jurnal Matematika Ilmiah STKIP Muhammadiyah Kuningan

Vol. 5 No. 2 November 2019

E-ISSN : 2654-833X

P-ISSN : 2443-3500

\title{
Pengaruh Kemampuan Spasial terhadap Hasil Belajar Matematika Siswa
}

Sarah Inayaha), Rani Sugiarnib)

a) Pendidikan Matematika, Fakultas Keguruan dan IImu Pendidikan, Universitas

Suryakancana

inayahsarah@gmail.com

b) Pendidikan Matematika, Fakultas Keguruan dan IImu Pendidikan, Universitas Suryakancana ranisugiarni@gmail.com

$\frac{\text { Article Info }}{\text { Keywords : spatial ability; }}$ learning outcomes; geometry

Submited: 2019-10-10 Published: 12/4/2019
The topic of geometry is accepted difficult by students because it deals with special abilities to describe spatial abilities. The difficulty of students in calculating the basis of mathematics and the difficulty of imagining like geometry material that illustrates imagining space and measuring the location of points, lines, fields and angles. The purpose of this study is to learn about spatial ability of student mathematics learning outcomes. The method used in this study is a research method that uses facts or causal research using a quantitative approach. This research was conducted in class XI OTKP Vocational High School Al-Madina Cianjur which was held by 22 students. Al Madina Vocational School is located at Caringin Street, Limbangan Sari, Cianjur District, Cianjur Regency. From the results of the study showed that the spatial ability and mathematics learning outcomes of students have a high and have a positive type of relationship with the coefficient obtained 0.869. Spatial learning has an interest in mathematics learning outcomes by $75.5 \%$ while $24.5 \%$.

130

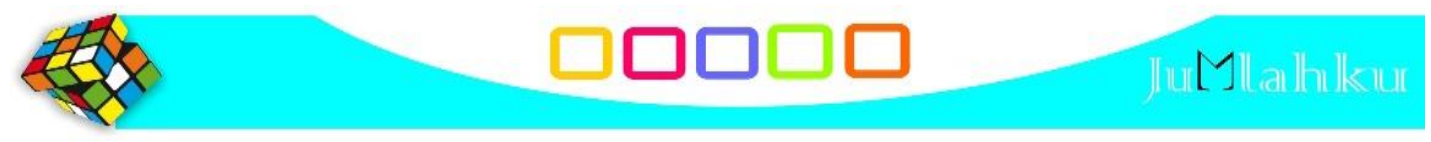


Kata Kunci:

kemampuan spasial, hasil belajar, geometri
Topik geometri dirasakan sulit oleh siswa karena berhubungan dengan kemampuan khusus yakni kemampuan spasial. kesulitan siswa yaitu dalam perhitungan dasar matematika dan sulitnya membayangkan seperti materi geometri yang abstrak membayangkan bangun ruang serta mengukur letak jarak titik, garis, bidang dan sudut. Tujuan dari penelitian ini untuk mengetahui pengaruh kemampuan spasial terhadap hasil belajar matematika siswa. Metode yang digunakan dalam penelitian ini yaitu metode penelitian korelasi yang bersifat ekpost facto atau causal research dengan menggunakan pendekatan kuantitatif. Penelitian ini dilaksanakan di kelas XI OTKP SMK Al-Madina Cianjur yang berjumlah 22 siswa. SMK Al Madina beralamat di Jalan Caringin, Limbangan Sari, Kecamatan Cianjur, Kabupaten Cianjur. Dari hasil penelitian menunjukkan antara kemampuan spasial dan hasil belajar matematika siswa memiliki korelasi yang tinggi dan memiliki jenis hubungan yang positif dengan koefisien korelasi yang diperoleh yaitu 0,869 . Kemampuan spasial memiliki pengaruh terhadap hasil belajar matematika sebesar $75,5 \%$ sedangkan $24,5 \%$ dipengaruhi faktor lain yang tidak diukur dalam penelitian ini. 


\section{PENDAHULUAN}

\begin{tabular}{lcr}
\multicolumn{1}{c}{ Saat } & ini di Indonesia & setiap \\
lembaga & persekolahan & telah \\
mendapatkan & keleluasaan & untuk
\end{tabular} mengelola pelaksanaan pembelajaran sesuai karakteristik lembaga tersebut. Keleluasaan tersebut disebut dengan otonomi sekolah. Melalui otonomi sekolah diharapkan setiap lembaga persekolahan menunjukkan keadaan yang mandiri, dapat melaksanakan kegiatan sesuai dengan potensi yang dimiliki dan mampu melaksanakan kegiatan secara bertanggung jawab. Melalui otonomi sekolah Clark,D (2009) menemukan peningkatan prestasi dari para siswa di Inggris. Hasil tersebut didapat karena otonomi memberikan pimpinan sekolah keleluasaan untuk menempatkan guru untuk dapat menggunakan keunggulan dari sumber daya mereka.

Keleluasaan yang dimiliki setiap sekolah tetap berpanduan sama yakni undang-undang sistem pendidikan nasional. Selain itu pemerintah menyelenggarakan penilaian bagi siswa sebagai penilaian yang berstandar nasional. Penilaian tersebut dipandang perlu karena sebagai upaya dalam penjaminan mutu di lembaga persekolahan. Penilaian tersebut dinamakan Ujian Nasional. Ujian Nasional (UN) ditujukan untuk menilai pencapaian kompetensi pada mata pelajaran tertentu dan digunakan untuk penentuan kelulusan peserta didik dari satuan pendidikan tersebut.

Adapun mata pelajaran yang menjadi mata pelajaran UN di semua jenjang diantaranya matematika, bahasa Indonesia, dan bahasa inggris. Mata pelajaran lain seperti IPA, IPS, antropologi, kompetensi keahlian dan lain sebagainya disesuaikan dengan jenjang dan jurusan. Diantara tiga mata pelajaran dasar yang diujikan pada UN yakni matematika, bahasa Indonesia, dan bahasa inggris, capaian rata-rata nilai terendah adalah pada mata pelajaran matematika (Puspendik kemdikbud). Untuk tingkat SMK rata-rata nilai UN matematika tahun 2019 adalah 35,26. Dibandingkan tahun 2018 memang mengalami sedikit peningkatan, yakni rata-rata UN matematika pada tahun 2018 adalah 33,73. Masih sangat jauh dari yang diharapkan dan menjadi yang terendah dibandingkan dengan mata pelajaran lainnya.

Terdapat berbagai topik dalam matematika yang menjadi bahasan dalam UN. Untuk SMK diantaranya aljabar, geometri, trigonometri, statistika dan kalkulus. Diantara lima topik tersebut, geometri merupakan topik yang paling rendah persentase nya dijawab benar oleh siswa (Puspendik kemdikbud). Berdasarkan data tersebut dapat disimpulkan bahwa topik geometri merupakan topik yang dinilai sulit bagi siswa khusus nya siswa SMK.

Hasil wawancara dengan guru matematika SMK Al-Madina kesulitan siswa yaitu dalam perhitungan dasar matematika dan sulitnya membayangkan seperti materi geometri yang abstrak membayangkan bangun ruang serta mengukur letak jarak titik, garis, bidang dan sudut. Guru hanya memberi

132
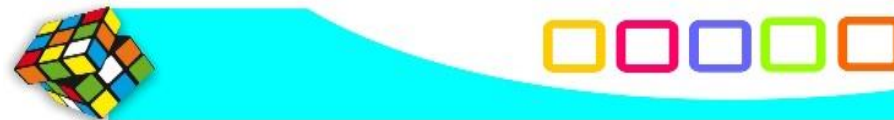
penjelasan sederhanya dan latihan soal dari buku yang ada disekolah serta terbatas dikelas tanpa melatih keterampilan membaca memahami masalah dengan memberikan lembar kerja siswa khusus sehingga mengakibatkan minat baca dan kemampuan spasial rendah.

Topik geometri dirasakan sulit oleh siswa karena berhubungan dengan kemampuan khusus yakni kemampuan spasial. Kemampuan spasial merupakan proses mental dalam mempersepsi, menyimpan, mengingat, mengkreasi, mengubah, dan mengkomunikasikan bangun ruang (Linn dan Petersen. 1985). Menurut National Academy of Science (2006) berpikir spasial merupakan kumpulan dari ketrampilan-keterampilan kognitif, yaitu terdiri dari gabungan tiga unsur yaitu konsep keruangan, alat representasi, dan proses penalaran. Kemampuan spasial sangat penting untuk ditingkatkan. Hal ini mengacu pada penelitian yang dilakukan oleh National Academy of Science (2006) yang mengemukakan bahwa setiap siswa harus berusaha mengembangkan kemampuan dan penginderaan spasialnya yang sangat berguna dalam memahami relasi dan sifat-sifat dalam geometri untuk memecahkan masalah matematika dan masalah dalam kehidupan sehari-hari.

Menurut Guay dan McDaniel (1977) kemampuan spasial mempunyai hubungan positif dengan matematika pada anak usia sekolah. Banyak penelitian lainnya yang juga menemukan hubungan antara kemampuan spasial dan matematika. Orang yang melakukan tugas spasial dengan baik juga berkinerja lebih baik pada tes kemampuan matematika (Burnett, Lane, \& Dratt, 1979; Casey, Nuttall, \& Pezaris, 2001; Geary, Hoard, Byrd-Craven, Nugent, \& Numtee, 2007; Holmes, Adams, \& Hamilton, 2008; Kyttälä, Aunio, Lehto, Van Luit, \& Hautamaki, 2003; Lubinski \& Benbow, 1992; McKenzie, Bull, \& Gray, 2003; Mclean \& Hitch, 1999; Rasmussen \& Bisanz, 2005).

Sejalan dengan pendapat tersebut Bishop (2008) menyatakan bahwa kemampuan spasial adalah kemampuan kunci yang mendasari kemampuan matematika. Sedangkan hasil belajar merupakan kemampuan yang diperoleh siswa melalui pengalaman belajarnya dan diukur melalui tes. Setelah siswa mendapat pembelajaran matematika kemudian diberikan tes maka diperoleh hasil yang menggambarkan hasil belajar matematika. Hasil belajar matematika menggambarkan sejauh mana kemampuan matematika yang telah ia capai dan kemampuan tersebut berhubungan bahkan kuncinya adalah kemampuan spasial yang ia miliki.

Berdasarkan uraian di atas mengenai kemampuan spasial dan hasil belajar matematika, penulis terotivasi untuk melakukan penelitian dengan judul "Pengaruh Kemampuan Spasial Terhadap Hasil Belajar Matematika Siswa"

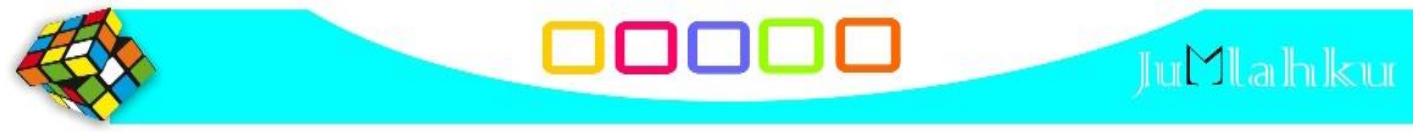




\section{METODE}

Metode yang digunakan dalam penelitian ini yaitu metode penelitian korelasi yang bersifat ekpost facto atau causal research dengan menggunakan pendekatan kuantitatif. Pada penelitian ini peneliti tidak memberikan perlakuan kepada kelompok subjek yang diteliti. Penelitian ini dimaksudkan untuk mendapatkan gambaran dan keterangan mengenai kemampuan spasial dan hasil belajar matematika siswa serta mengetahui bagaimana hubungan dan pengaruh kemampuan spasial tersebut terhadap hasil belajar siswa tersebut (Widarto, M. P, 2013).

Penelitian ini dilaksanakan di kelas XI OTKP SMK Al-Madina Cianjur yang berjumlah 22 siswa. SMK Al Madina beralamat di Jalan Caringin, Limbangan Sari, Kecamatan Cianjur, Kabupaten Cianjur.

Instrumen yang digunakan dalam penelitian ini terdiri dari instrument tes. Instrument tes yang digunakan dalam penelitian ini bertujuan untuk mengetahui gambaran mengenai kemampuan spasial dan hasil belajar siswa. Untuk mengetahui hasil belajar siswa tes yang digunakan berupa tes sumatif berupa Ujian akhir semester genap. Tes sumatif ditujukan untuk mengetahui penguasaan siswa dalam sejumlah materi pelajaran yang telah dipelajari. Pengertian sejumlah berkonotasi banyak, sehingga tes sumatif ruang lingkup materinya cukup banyak/ luas terdiri dari beberapa pokok bahasan.

\section{HASIL DAN PEMBAHASAN}

Penelitian ini mengenai kemampuan spasial dan hasil belajar siswa. Penelitian ini dilakukan di SMK AIMadina Cianjur pada satu kelas yaitu kelas XI OTKP sebagai kelas observasi dengan siswa berjumlah 22 orang. Pokok bahasan yang diajarkan selama pengamatan ini adalah materi geometri mengenai jarak pada ruang dimensi tiga. Penelitian ini dilakukan untuk mengetahui bagaimana kemampuan spasial dan hasil belajar siswa serta bagaimana pengaruh kemampuan spasial terhadap hasil belajar siswa. Penelitian dilakukan dengan memberikan tes kemampuan spasial yang berbentuk soal uraian kemudian di akhir semester memberikan tes berupa ujian akhir semester. Instrumen yang digunakan untuk mengukur kemampuan spasial sebelumnya telah diuji cobakan dan telah dianalisis karakteristiknya berupa uji validitas, dan uji reliabilitas.

134

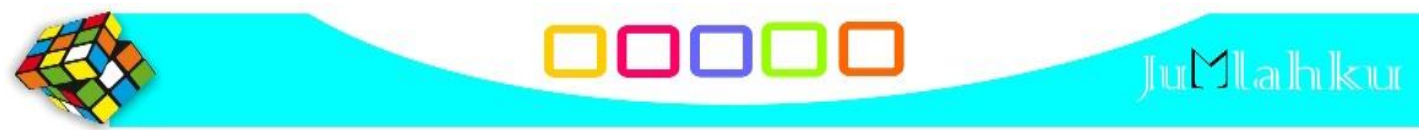


Setelah pengambilan data dilakukan maka selanjutnya dilakukan analisis terhadap data tes kemampuan spasial dan hasil belajar siswa. Berdasarkan penelitian yang telah dilakukan, didapatkan hasil ditunjukan pada tabel berikut:

Tabel 1. Kemampuan Spasial dan Hasil belajar matematika Siswa

\begin{tabular}{|l|l|l|l|l|l|}
\hline No & Aspek & $\begin{array}{l}\text { Nilai } \\
\text { minimum }\end{array}$ & $\begin{array}{l}\text { Nilai } \\
\text { maksimum }\end{array}$ & $\begin{array}{l}\text { Nilai rata- } \\
\text { rata }\end{array}$ & $\begin{array}{l}\text { Standar } \\
\text { deviasi }\end{array}$ \\
\hline 1 & Kemampuan Spasial & 31 & 88 & 63,95 & 17,13 \\
\hline 2 & $\begin{array}{l}\text { Hasil Belajar } \\
\text { Matematika }\end{array}$ & 31 & 91 & 64,00 & 16,78 \\
\hline
\end{tabular}

Berdasarkan data pada tabel diperoleh bahwa nilai minimum untuk kemampuan spasial adalah 31 dengan nilai maksimum 88. Diperoleh nilai rata-rata untuk kemampuan spasial adalah 63,95 dengan standar deviasi 17,13 . Sedangkan untuk hasil belajar matematika diperoleh nilai minimum 31 nilai maksimum 91, nilai ratarata 64,00 dengan standar deviasi 16,78. Jika dibandingkan antara kedua nilai tersebut, nampak bahwa pada kelas tersebut hasil belajar yang diperoleh dari nilai ujian akhir semester memiliki jangkauan antara nilai maksimum dan nilai minimum yang sangat besar jika dibandingkan dengan kemampuan spasial. Akan tetapi pada tes kemampuan spasial didapatkan hasil yang lebih beragam diantara keseluruhan siswa. Selain itu perbedaan rata-rata diantara kedua hasil tes menunjukkan hasil yang hampir sama, hanya terpaut selisih 0,05. Hal ini bisa terjadi oleh karena jumlah dan soal juga cakupan materi pada kedua jenis tes. Pada ujian akhir semester jumlah soal lebih banyak dibandingkan dengan soal pada tes kemampuan spasial yakni berjumlah 25 dengan 20 soal diantaranya berbentuk pilihan ganda dan 5 soal uraian, sedangkan pada tes kemampuan spasial jumlah soal hanya 5 yang semuanya berbentuk soal uraian. Selain itu, topik pada ujian akhir semester sangat banyak yang merupakan kumpulan topik dalam satu semester sedangkan topik pada tes kemampuan spasial adalah jarak pada ruang dimensi tiga dimana topik pada tes kemampuan spasial juga menjadi bagian pada topik ujian akhir semester.

Untuk mengetahui apakah kemampuan spasial memiliki pengaruh terhadap hasil 
belajar siswa maka perlu analisis statistik. Sebelum melakukan analisis tersebut dilakukan uji prasyarat yakni uji normalitas dan linearitas. Dalam melakukan seluruh analisis tersebut, peneliti menggunakan bantuan software SPSS (Statistical Package for Social Sciences) versi 22.

Teknik analisis data yang dipilih peneliti pada penelitian ini yaitu statistik deskriptif, sehingga variabel-variabel yang diteliti dapat diungkapkan satu per satu serta teknik analisis kuantitatif dengan mengolah data yang telah diperoleh dari kelas yang diteliti.

Teknik analisis data yang dilakukan dalam penelitian ini yaitu analisis regresi dengan menggunakan metode estimasi Ordinary Least Square (OLS). Hasil estimasi regresi kemudian akan dianalisis dengan beberapa uji yaitu untuk melihat seberapa baik garis regresi dengan konsep koefisien determinasi, uji t, dan uji $F$. Analisis regresi digunakan untuk menelaah hubungan antara dua variabel atau lebih, terutama untuk menelusuri pola hubungan yang modelnya belum diketahui secara pasti.
Karena teknik analisis regresi yang digunakan menggunakan metode Ordinary Least Square (OLS), maka sebelum dianalisis, data tersebut harus memenuhi uji prasyarat analisis yaitu uji asumsi klasik. Pengujian asumsi klasik tersebut ialah uji normalitas dan uji liniearitas.

$\mathrm{H}_{0}$ : data skor $>0,05$ distribusi normal

$\mathrm{H}_{1}$ : data skor $<0,05$ distribusi tidak normal

Hasil uji normalitas dapat dilihat pada tabel berikut : 
Tabel 2. Hasil Uji Normalitas One-Sample Kolmogorov-Smirnov Test

\begin{tabular}{|ll|l|}
\hline & & Unstandardized Residual \\
\hline $\mathrm{N}$ & & 22 \\
Normal Parameters $\mathrm{a}, \mathrm{b}$ & Mean & .0000000 \\
& Std. Deviation & 8.30123356 \\
Most Extreme Differences & Absolute & .182 \\
& Positive & .182 \\
& Negative & -.162 \\
Test Statistic & & .182 \\
Asymp. Sig. (2-tailed) & & $.055^{\mathrm{c}}$ \\
\hline
\end{tabular}

a. Test distribution is Normal.

b. Calculated from data.

c. Lilliefors Significance Correction.

Berdasarkan tabel tersebut dilihat nilai sig. Kolmogorov-Smirnova yaitu $=0,055>0,05$. Berdasarkan hasil tersebut maka $\mathrm{H}_{0}$ diterima yang artinya adalah data skor data galat taksiran atau residu pada uji regresi yang dilakukan distribusi normal. Karena data skor data galat taksiran atau residu pada uji regresi yang dilakukan distribusi normal maka analisis dapat dilanjutkan untuk uji linearias.

$\mathrm{H}_{0}$ : data skor $>0,05$ hubungan antar variabel bersifat liniear

$\mathrm{H}_{1}$ : data skor $<0,05$ hubungan antar variabel bersifat tidak liniear

Berikut ini akan disajikan hasil pengujian liniearitas, secara lengkap hasil tersebut dapat dilihat pada tabel berikut: 
Tabel 3. Hasil Uji Linearitas ANOVA Table

\begin{tabular}{|c|c|c|c|c|c|c|c|}
\hline & $\begin{array}{l}\text { Sum of } \\
\text { Squares }\end{array}$ & Df & $\begin{array}{l}\text { Mean } \\
\text { Square }\end{array}$ & $\mathrm{F}$ & Sig. \\
\hline \multirow{5}{*}{$\begin{array}{l}\text { Hasil_Belajar } \\
\text { * Spasial }\end{array}$} & \multirow{3}{*}{$\begin{array}{l}\text { Betweer } \\
\text { Groups }\end{array}$} & (Combined) & 4878.383 & 8 & 609.798 & 7.640 & .001 \\
\hline & & Linearity & 4468.880 & 1 & 4468.880 & 55.989 & .000 \\
\hline & & $\begin{array}{l}\text { Deviation } \\
\text { from } \\
\text { Linearity }\end{array}$ & 409.503 & 7 & 58.500 & .733 & .649 \\
\hline & \multicolumn{2}{|c|}{ Within Groups } & 1037.617 & 13 & 79.817 & & \\
\hline & \multicolumn{2}{|l|}{ Total } & 5916.000 & 21 & & & \\
\hline
\end{tabular}

Berdasarkan hasil tabel tersebut diketahui bahwa nilai sig. pada baris Deviation from Linearity yaitu $0,649>0,05$ sehingga terima $\mathrm{H}_{0}$ yaitu hubungan antar variabel bersifat liniear. Karena hubungan antar variabel tersebut bersifat liniear maka analisis dengan model regresi linear sederhana dapat digunakan.

Selanjutnya akan dilakukan analisis data mengenai pengaruh kemampuan spasial terhadap hasil belajar matematika siswa. Data hasil penelitian ini telah diolah melalui program SPSS V.22 dengan analisis regresi linier sederhana.

$\mathrm{H}_{0}$ : data skor > 0,05 tidak ada pengaruh kemampuan spasial siswa tehadap hasil belajar matematika

$\mathrm{H}_{1}$ :data skor < 0,05 ada pengaruh kemampuan spasial siswa tehadap hasil belajar matematika

Hasil perhitungan koefisien regresi tersebut ditunjukan pada tabel sebagai berikut: 
Table 4. Hasil Koefisien Regresi Coefficients ${ }^{a}$

\begin{tabular}{|l|l|l|l|l|}
\hline \multicolumn{2}{|l|}{ Unstandardized Coefficients } & Standardized Coefficients & & \\
\cline { 1 - 3 } B & Std. Error & Beta & T & Sig. \\
\hline 9.540 & 7.163 & & 1.332 & .198 \\
.852 & .108 & .869 & 7.859 & .000 \\
\hline
\end{tabular}

a. Dependent Variable: Hasil_Belajar

Selanjutnya berdasarkan hasil tersebut dapat dirumuskan suatu persamaan regresi linier sederhana sebagai berikut:

$\boldsymbol{Y}=9,540+0,852 \boldsymbol{X}$
Untuk mengetahui ada tidaknya pengaruh kemampuan spasial siswa tehadap hasil belajar matematika dapat dilihat hasil uji $F$ pada output SPSS V.22 didapatkan hasil perhitungan sebagai berikut:

Tabel 5. Hasil Uji F ANOVAa

\begin{tabular}{|c|c|c|c|c|c|c|}
\hline Model & & $\begin{array}{ll}\text { Sum } & \text { of } \\
\text { Squares }\end{array}$ & df & Mean Square & $\mathrm{F}$ & Sig. \\
\hline 1 & $\begin{array}{l}\text { Regression } \\
\text { Residual } \\
\text { Total }\end{array}$ & $\begin{array}{l}4468.880 \\
1447.120 \\
5916.000\end{array}$ & $\begin{array}{l}1 \\
20 \\
21\end{array}$ & $\begin{array}{l}4468.880 \\
72.356\end{array}$ & 61.762 & $.000^{\mathrm{b}}$ \\
\hline
\end{tabular}

a. Dependent Variable: Hasil_Belajar

b. Predictors: (Constant), Spasial

Berdasarkan hasil tersebut maka menunjukkan bahwa nilai Sig. = $0,000<0,05$ sehingga $\mathrm{H}_{0}$ ditolak, artinya kemampuan spasial memiliki pengaruh terhadap hasil belajar matematika. Sedangkan untuk mengetahui koefisien korelasi antara kemampuan representasi matematis siswa dan kepercayaan dirinya dan koefisien detrminasi dapat dilihat pada table berikut: 
Table 6. Hasil Uji Signifikansi Koefisien Korelasi Model Summary ${ }^{b}$

\begin{tabular}{|l|l|l|l|l|}
\hline Model & $\mathrm{R}$ & $\mathrm{R}$ Square & $\begin{array}{l}\text { Adjusted } \\
\text { Square }\end{array}$ & $\begin{array}{l}\text { Std. Error of } \\
\text { the Estimate }\end{array}$ \\
\hline 1 & $.869^{\mathrm{a}}$ & .755 & .743 & 8.506 \\
\hline
\end{tabular}

a. Predictors: (Constant), Spasial

b. Dependent Variable: Hasil_Belajar

Dari hasil tabel di atas didapatkan nilai $R$ yaitu koefisien korelasi yang tinggi yaitu 0,869 karena karena angka koefisien korelasi bernilai positif. Berdasarkan hasil tersebut maka diketahui bahwa terdapat hubungan positif tinggi antara kemampuan spasial dan hasil belajar matematika siswa.

Besarnya pengaruh variabel independent terhadap variabel dependent dapat dilihat pada nilai koefisien determinasi $\left(R^{2}\right)$ yaitu sebesar 0,755 . Dengan demikian maka besarnya koefisien determinasi $=100 \%$ x $0,755=75,5 \%$. Artinya bahwa $75.5 \%$ variasi variabel hasil belajar matematika siswa dapat dijelaskan oleh variabel kemampuan spasial yang dimilikinya atau dapat dikatakan bahwa kemampuan spasial memiliki pengaruh terhadap hasil belajar matematika sebesar $75,5 \%$. Sehingga faktor lain berada pada rentang 0,7 - 0,9 dan memiliki jenis hubungan yang positif

yang tidak diukur dalam penelitian ini sebesar 24,5\%. Ada beberapa kemungkinan faktor lain yang mempengaruhi hasil belajar matematika siswa diantaranya faktor afektif yang dimiliki maupun kemampuan matematis lain nya. Melihat porsi pengaruh dari kemampuan spasial lebih besar maka dapat dikatakan penting untuk memperhatikan kemampuan tersebut dalam pembelajaran demi didapatkannya hasil belajar matematika siswa yang baik

\section{PENUTUP}

Simpulan

Dari hasil penelitian menunjukkan antara kemampuan spasial dan hasil belajar matematika 
siswa memiliki korelasi yang tinggi dan memiliki jenis hubungan yang positif dengan koefisien korelasi yang diperoleh yaitu 0,869. Kemampuan spasial memiliki pengaruh terhadap hasil belajar matematika sebesar $75,5 \%$ sedangkan $24,5 \%$ dipengaruhi faktor lain yang tidak diukur dalam penelitian ini.

\section{Saran}

Kajian mengenai kemampuan spasial dan hasil belajar matematika siswa ini dapat dijadikan acuan maupun dasar bagi guru di sekolah khususnya bagi guru matematika dalam mengarahkan, merencanakan dan melaksanakan pembelajaran. Namun masih perlu pengkajian lebih mendalam mengenai kemampuan spasial dan hasil belajar matematika siswa ini karena tidak cukup hanya mengukur keduanya melalui kajian tes satu kali dan ujian akhir semester saja. Perlu diadakan penelitian lebih lanjut untuk dapat mengukur kemampuan spasial dan hasil belajar matematika siswa secara lebih mendalam serta penelitian terhadap tindakan dalam pembelajaran yang tepat untuk digunakan untuk meningkatkan kemampuan spasial dan hasil belajar matematika siswa.

\section{Ucapan Terima Kasih}

Tim mengucapan terimakasih kepada semua pihak Universitas Suryakanana yang ikut membantu dalam pelaksanaan penelitian dan DDRPM-
Ristekdikti yang telah memberikan dukungan materi sehingga bisa terlaksana penelitian ini.

\section{DAFTAR PUSTAKA}

Bishop, Alan (2008) Critical Issues in Mathematics Education- Springer New York USA

Burnett, S. A., Lane, D. M., \& Dratt, L. M. (1979). Spatial visualization and sex differences in quantitative ability. Intelligence, 3, 345-354.

Casey, M. B., Nuttall, R. L., \& Pezaris, E. (2001). Spatial-mechanical reasoning skills versus mathematical self-confidence as mediators of gender differences on mathematics subtests using crossnational gender-based items. Journal for Research in Mathematics Education, 32(1), 2857.

Clark, Damon. (2009) The Performance and Competitive Effects of School Autonomy. Journal of Political Economy, 2009, vol. 117, no. 4 p.745-783

Geary, D. C., Hoard, M. K., ByrdCraven, J., Nugent, L., \& Numtee, C. (2007). Cognitive mechanisms underlying achievement deficits in children with mathematical learning disability. Child Development, 78, 1343-1359. 
Guay, R., \& McDaniel, E. 1977. The relationship between mathematics achievement and spatial abilities among elementary school children. Journal for Research in Mathematics Education, 8(3), 211215. doi:10.2307/748522

Holmes, J., Adams, J. W., \& Hamilton, C. J. (2008). The relationship between visuospatial sketchpad capacity and children's mathematical skills. European Journal of Cognitive Psychology, 20(2), $272-289$.

Kyttälä, M, Aunio, P, Lehto, J. E., Van Luit, J., \& Hautamaki, J. (2003). Visuospatial working memory and early numeracy. Educational and Child Psychology, 20, 65-76.

Linn, M., \& Petersen, A. 1985. Emergence and characterization of sex differences in spatial ability: a meta-analysis. Child Development, $56(6)$, 1479-1498. doi:10.2307/1130467

Lubinski, D., \& Benbow, C.P. (1992). Gender differences in abilities and preferences among the gifted: Implications for the math/science pipeline. Current Directions in Psychological Science, 1(2), 61-66. children's arithmetical performance. Educational and Child Psychology, 20, 93-108.

McLean, J. F., \& Hitch, G. J. (1999). Working memory impairments in children with specific arithmetic learning difficulties. Journal of Experimental Child Psychology, 74, 240-260.

National Academy of Science (2006). Learning to Think Spatially. Washington DC: The National Academics Press.

Puspendik kemdikbud. Laporan Hasil Ujian Nasional. Tersedia: https://hasilun.puspendik.kemdikbu d.go.id [1 Juni 2019]

Widarto, M. P. (2013). Penelitian Ex Post Facto. Fakultas Teknik: Universitas Negeri Yogyakarta.

McKenzie, B., Bull, R., \& Gray, C. (2003). The effects of phonological and visual-spatial interference on 